\title{
Fuchs syndrome: a case of fever, mucositis and conjunctivitis
}

\author{
Chun Yi Ting, ${ }^{1}$ Raveen Shahdadpuri ${ }^{2}$
}

'Department of Paediatrics, KK Women's and Children's Hospital, Singapore ${ }^{2}$ Department of Paediatrics, KK Women's and Children's Hospital, Singapore

\section{Correspondence to Dr Chun Yi Ting, chunyi.ting@mohh.com.sg}

Accepted 11 January 2018

\section{DESCRIPTION}

A 5 -year-old boy presented with fever and cough of 2 weeks' duration, conjunctivitis and lip swelling with blistering for 6 days, and 1 day of skin rash. His past medical history was significant for incomplete Kawasaki disease (KD) at 3 years of age with no cardiac sequelae. Significant findings on physical examination included bilateral conjunctival injection with perilimbic sparing, red and cracked lips with crusting, oral mucositis and ulcerations of the buccal mucosae and tongue (figure 1), and a mild generalised maculopapular rash. He was systemically well otherwise, and there were no target lesions evident on his skin.

Differential diagnoses at that point included recurrent incomplete KD, Stevens-Johnson syndrome (SJS) and gingivostomatitis. However, oral mucositis was not consistent with KD. Furthermore, the absence of any skin involvement, which is typically seen in SJS, made SJS less likely. Lastly, the prolonged fever, red eyes and rash did not support the diagnosis of gingivostomatitis.

Laboratory investigations revealed mild thrombocytosis of $477 \times 10^{9} / \mathrm{uL}$ and raised erythrocyte sedimentation rate of $141 \mathrm{~mm} /$ hour. Transthoracic echocardiogram revealed a dilated left coronary artery, and a clinical diagnosis of recurrent incomplete KD was made. As such, he was treated with oral aspirin and intravenous immunoglobulin. Mycoplasma pneumoniae serology titres

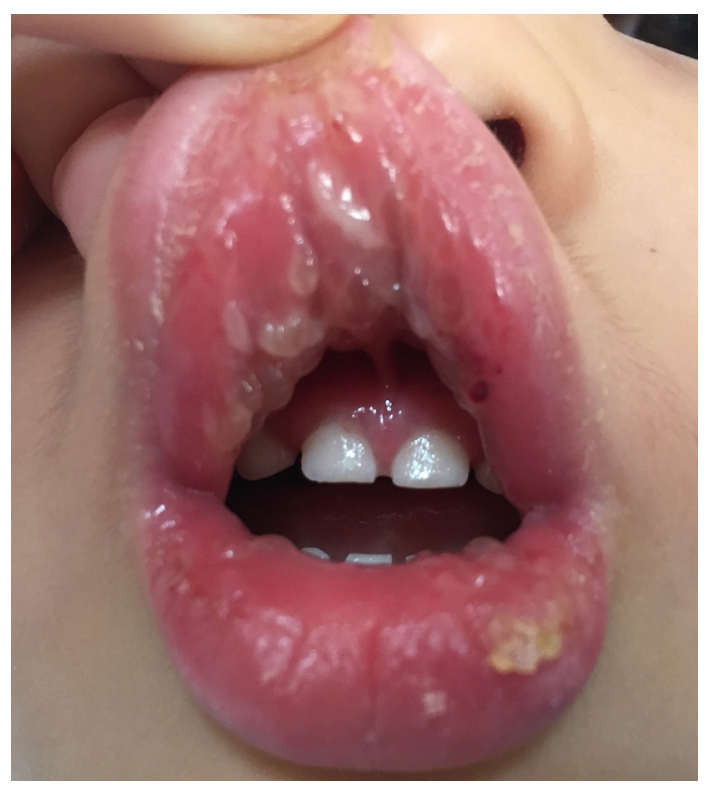

Figure 1 Oral mucositis with blistering of lips in a patient with Fuchs syndrome. subsequently returned positive $(>640)$ and he was commenced on a course of oral azithromycin.

Clinically, this boy had concurrent SJS without typical skin lesions (Fuchs syndrome) and incomplete $\mathrm{KD}$, both triggered by $\mathrm{Myco}$ plasma infection.

Fuchs syndrome is an atypical variant of SJS characterised by the involvement of two or more mucosal surfaces without the typical skin involvement such as purpuric macules, targetoid lesions and full-thickness epidermal necrosis. This commonly affects the mucosa of the mouth, genitalia and conjunctiva and can be seen in children and adolescents. ${ }^{1}$ In fact, oral lesions with mucositis are most commonly seen, whereas ocular involvement occurs in $67 \%$ and genital involvement in $75 \%$ of all cases. It is known to be associated with $M$. pneumoniae infections. ${ }^{2}$ While uncommon, clinicians must be cognizant of this less common manifestation of SJS and consider M. pneumoniae as a likely cause. Treatment is supportive and macrolide antibiotics are the treatment of choice for children. With timely management, prognosis is excellent. ${ }^{3}$

\section{Learning points}

- Fuchs syndrome is a variant of Stevens-Johnson syndrome (SJS) without skin lesions and with only mucosal involvement, mostly affecting the mucosa of the mouth, genitalia and conjunctiva.

- It is important to consider Mycoplasma pneumoniae as a likely cause of SJS without skin lesions. Confirmation of the cause with serological or PCR testing is useful to allow for timely management.

Contributors Both authors were involved in the management of this patient. CYT reviewed the literature and drafted the manuscript. RS revised the manuscript and supervised the process. Both authors approved the final version published.

Competing interests None declared.

Patient consent Parental/guardian consent obtained.

Provenance and peer review Not commissioned; externally peer reviewed.

(C) BMJ Publishing Group Ltd (unless otherwise stated in the text of the article) 2018. All rights reserved. No commercial use is permitted unless otherwise expressly granted.

\section{REFERENCES}

1 Šternberský J, Tichý M. Fuchs' syndrome (Stevens-Johnson syndrome without skin involvement) in an adult male--a case report and general characteristics of the sporadically diagnosed disease. Acta Dermatovenerol Croat 2014;22:284-7. 
2 Meyer Sauteur PM, Gansser-Kälin U, Lautenschlager S, et al. Fuchs syndrome associated with Mycoplasma pneumoniae (Stevens-Johnson syndrome without skin lesions). Pediatr Dermatol 2011;28:474-6.
3 Li K, Haber RM. Stevens-Johnson syndrome without skin lesions (Fuchs syndrome): a literature review of adult cases with Mycoplasma cause. Arch Dermatol 2012;148:963-4.

Copyright 2017 BMJ Publishing Group. All rights reserved. For permission to reuse any of this content visit http://group.bmj.com/group/rights-licensing/permissions.

BMJ Case Report Fellows may re-use this article for personal use and teaching without any further permission.

Become a Fellow of BMJ Case Reports today and you can:

- Submit as many cases as you like

- Enjoy fast sympathetic peer review and rapid publication of accepted articles

- Access all the published articles

- Re-use any of the published material for personal use and teaching without further permission

For information on Institutional Fellowships contact consortiasales@bmjgroup.com

Visit casereports.bmj.com for more articles like this and to become a Fellow 